\title{
Dexchlorpheniramine Maleate
}

National Cancer Institute

\section{Source}

National Cancer Institute. Dexchlorpheniramine Maleate. NCI Thesaurus. Code C47478.

The maleate salt form of dexchlorpheniramine, an alkylamine, and first-generation histamine antagonist with anti-allergic activity. Dexchlorpheniramine maleate competitively blocks $\mathrm{H} 1$ receptors, thereby preventing the actions of histamine on bronchial smooth muscle, capillaries and gastrointestinal (GI) smooth muscle. This prevents histamine-induced bronchoconstriction, vasodilation, increased capillary permeability, and Gl smooth muscle spasms. 